\title{
European Union agri-food quality schemes for the protection and promotion of geographical indications and traditional specialities: an economic perspective
}

\author{
Agnieszka Hajdukiewicz
}

Department of Foreign Trade

Cracow University of Economics

Rakowicka 27, 31-510 Kraków, Poland

\begin{abstract}
The schemes for identifying and protecting the names of agricultural products and foods having specific qualities, have been launched by European Union as a part of its complex agricultural quality policy. The main objective of this article is to examine different aspects of three of the schemes, developed for products with specific characteristics resulting from a particular origin or farming method: PDO (Protected Designation of Origin), PGI (Protected Geographical Indication) and TSG (Traditional Speciality Guarantied). The focus is mainly on the economic issues of the production and marketing of products and foodstuffs registered under particular schemes. The methodology includes studying the existing literature and European regulations on the subject, collecting and analysing statistical data as well as examining a short practical case.

The economic theory suggests that PDO/PGI/TSG registration results in the higher ability of producers to compete in the market. The increasing number of registrations confirms the growing interest of producers in using it as a tool to create competitive advantage. However, a higher price for such products compared with a standard product, does not always translate into a market success, since producing them requires farmers to follow a certain specification and this may involve additional costs. The analysis of the Vistula Cherry case found that there are significant market opportunities for certified producers of high quality fruits due to excellent characteristics of their products, but at the same time they face certain external and internal challenges and need to further develop their production and marketing skills, within the framework of the local collective organization.
\end{abstract}

Key words: agricultural products, agroeconomy, foodstuffs, Protected Designation of Origin, Protected Geographical Indication, sour cherry, Traditional Speciality Guaranteed

\section{Abbreviations:}

AND - International - Agriculture Nutrition Développement, PGI - Protected Geographical Indication, PDO - Protected Designation of Origin, TSG - Traditional Speciality Guaranteed

\section{INTRODUCTION}

Consumers in the European Union and around the world show an increasing interest in the quality of food. They often expect even more then higher dietary, health and hygiene standards from the products they buy. Affluent discerning buyers are increasingly looking for provenance, taste, animal 
welfare aspects, environmental friendliness and other individual product characteristics, often attributed to the specific origin or production method. In the marketplace the demand for quality products meets the abundant supply of goods that takes full account of consumers' requirements. That indicates the 'quality turn' in the economy, from the 'industrial world', with its heavily standardized quality conventions and logic of mass commodity production, to the 'domestic world', where quality conventions embedded in trust, tradition and place support more differentiated, localized and eco friendly products and forms of economic organization (Goodman 2003). This movement leads to the growth of labelling schemes to guaranty different food qualities. In order to help European agricultural producers to adopt to the changes in customers' attitudes and meet demand for high quality products with individual characteristics linked to specific production methods, composition or origin, European Union developed three quality schemes regarding product indications and designations:

- Protected Designation of Origin (PDO) - refers to agricultural products and foodstuffs which are produced, processed and prepared in a given geographical area using recognised know-how.

- Protected Geographical Indication (PGI) -covers agricultural products and foodstuffs closely linked to the geographical area. At least one of the stages of production, processing or preparation takes place in the area.

- Traditional Speciality Guaranteed (TSG) - covers agricultural products or foodstuffs that are produced using traditional raw materials or traditional methods of production, or that have traditional composition (European Commission 2013).

EU-labelled products, with characteristics that are specific to a territory or to a particular production method, are supposed to enjoy high reputation and gain much higher prices than similar non-labelled products. Quite often, the quality and reputation of EU-labelled products are considered important development assets of the region. Polish producers of high quality agri-food products, such as the Vistula Cherry, are also able and expected to take advantage of the opportunity arising from joining the European food quality schemes.

The purpose of this paper is to examine in depth different aspects of the European product quality schemes - PDO, PGI and TSG. The main emphasis is however on their economic effects. In particular the paper attempts to explore the opportunities and problems that the registration of regional and traditional products may bring to the local production system. The focus is on quality schemes for agricultural products and foodstuffs. Wines and spirits are covered by specific legislation and are beyond the scope of a detailed analysis in this paper.

\section{THE EU LEGISLATION CONCERNING PRODUCT QUALITY SCHEMES}

Geographical indications and traditional specialities designations are important instruments of EU's product quality policy. Quality as a term is not easy to define. In the past, quality was commonly understood in terms of taste, ripeness, freshness, or flavour, as defined by actors involved in production, but recent consumer displeasure with the health, safety, homogeneity and environmental impacts of industrial farming finds expression through seeking alternatives to mass-produced, undifferentiated foods (Warner 2007). As Ilbery and Kneafsy (2000) underscore, however, quality is a highly subjective term. Food producers, distributors, and consumers may perceive product quality quite differently. Quality, therefore, must be understood as a contested notion which is constructed by actors attempting to build stable and lasting networks between themselves and others within the market arena. According to EU Green Paper quality is about meeting consumer expectations (Green Paper on agricultural product quality 2008). One of the important aspects of product quality, in its wide and modern meaning are quality attributes in an agricultural policy related to particular production methods often resulting from local expertise and traditions,

The legislation concerning product quality systems was developed step-by-step, from the development of special provisions for quality wines in the 1980s onwards. In 1992 the first European legislation geographical indications and protected designation of origin for agricultural product and foodstuffs (excluding spirit drinks and wine products) was adopted, inspired by existing national systems, for example the French AOC (Appellation d'Origine Contrôlée) and the Italian DOC (Denominazione d'Origine Controllata) systems (European Commission 2011).

The French AOC scheme is closely related to the concept of terroir (Barham 2003), which dates back 
to the $13^{\text {th }}$ century. Historically, terroir refers to an area or terrain, usually rather small, whose soil and microclimate impart distinctive qualities to food products. Figuratively, terroir can also designate a rural or provincial region that is considered to have a marked influence on its inhabitants.

A terroir product is characterised by a specific geographical origin, developed over a long period of interaction with the local traditions, local environment, and savoir faire. Such factors are considered in applications for an PDO/PGI label (Hegnes 2012).

The newest regulation on quality schemes for agricultural products and foodstuff entered into force on $3^{\text {rd }}$ January 2013 (Regulation (EU) No 1151/2012). It aims to help producers of agricultural products and foodstuffs to communicate the product characteristics and farming attributes of those products and foodstuffs to buyers and consumers, thereby ensuring:

a) fair competition for farmers and producers of agricultural products and foodstuffs having value-adding characteristics and attributes;

b) the availability to consumers of reliable information pertaining to such products;

c) respect for intellectual property rights; and

d) the integrity of the internal market.

The important challenge of the agricultural policy of the EU is to maintain the diversity of the agricultural production in the Union. But producers can only continue to produce a diverse range of quality products if they are rewarded fairly for their effort. This requires that they are able to communicate to buyers and consumers the characteristics of their product under conditions of fair competition. It also requires them to be able to correctly identify their products on the market place. That can be achieved through using one of the schemes presented below.

\section{PROTECTED DESIGNATION OF ORIGIN (PDO)}

A scheme for protected designation of origin is one of two schemes (together with PGI) which was established to support producers of certain products linked to a geographical area. Protected Designation of Origin is a name which identifies a product:

- originating in a specific place, region or, in exceptional cases, a country;

- whose quality or characteristics are essentially or exclusively due to a particular geographical environment with its inherent natural and human factors; and

- the production steps of which all take place in the defined geographical area.

Thus, products bearing the PDO logo (Fig. 1a) have proven characteristics resulting solely from the terrain and abilities of producers in the region of production with which they are associated. PDO products thus require all stages of the food production process to be carried out in the area concerned. There must be an objective and close link between the product's features and its geographical origin.

This link is the key notion: only specific skills or specific natural conditions in a given area are not enough. The specificity of this link is the protected notion and makes the identity of the product. A similar product produced with the same skills in another area can't be exactly the same. A product made in the same area without respecting the specific link is not the same neither. In this frame, new technologies can be used if they respect this link. When the product is bought by a consumer, this one buys this specificity (Marty 1997).

Examples of products that are registered as PDO are Italian 'Prosciutto Toscano', French 'Roqeufort', Spanish 'Jamón de Huelva' and UK's 'Shetland lamb'. In Poland products with PDO status comprise among others 'Bryndza Podhalańska', also known as bundz sheep's milk cheese, and 'Oscypek' smoked sheep's milk cheese, that were the first Polish products which have been registered by the European Commission and may use the PDO logo ${ }^{1}$.

Examples of fruit and vegetable with PDO logo are French 'Olive de Nîmes', Italian 'Pistacchio verde di Bronte', British 'Jersey Royal potatoes', Polish 'Wiśnia nadwiślanka' or Czechish 'Všestarská cibule'.

\footnotetext{
${ }^{1}$ Slovakia objected to the registration in of 'Oscypek' stating that registering the Polish designation would undermine the designation 'Slovenský oštiepok', for which Slovakia had applied to the Commission for registration as a protected geographical indication. Finally Poland and Slovakia reached agreement in which they recognize that the designations 'Oscypek' and 'Slovenský oštiepok' refer to cheeses that are now produced quite differently, despite the fact that they share the same history and tradition. That mean that both of them can be registered separately under the EU quality schemes. According to Poland and Slovakia, the key differences between the two cheeses (concerning the raw material used, the production method and physical, chemical and organoleptic properties) should not give rise to confusion amongst consumers.
} 


\section{PROTECTED GEOGRAPHICAL INDICATION (PGI)}

Protected Geographical Indication means a name which identifies a product:

- originating in a specific place, region or country;

- whose given quality, reputation or other characteristic is essentially attributable to its geographical origin; and

- at least one of the production steps of which take place in the defined geographical area.

Products carrying the PGI logo (Fig. 1b) have a specific characteristic or reputation associating them with a given area, and at least one stage in the production process must be carried out in that area, while the raw materials used in production may come from another region.

Examples of PGI products are German 'Dortmunder Bier', French 'Volailles de Normandie' and Irish 'Clare Island Salmon', all meeting particular quality specifications. The list of names of fruits and vegetables with PGI status include among others: Spanish 'Melón de la Mancha', German 'Lüneburger Heidekartoffeln', "Gurken von der Insel Reichenau' and 'Spargel aus Franken/Fränkischer Spargel/Franken-Spargel', Polish 'Truskawka kaszubska' lub 'Kaszëbskô malëna', Portuguese 'Citrinos do Algarve'.

\section{TRADITIONAL SPECIALITY GUARANTEED (TSG)}

The Traditional Speciality Guaranteed logo (Fig. 1c) is used for products with distinctive features which either have traditional ingredients or are made using traditional methods.

TSG refers to a specific product or foodstuff that:

- results from a mode of production, processing or composition corresponding to traditional practice for that product or foodstuff; or

- is produced from raw materials or ingredients that are those traditionally used.

Among the product names in this group are Italian 'Mozarella' cheese, 'Pizza Napoletana' and Swedish 'Falukorv'. Polish TSG products include inter alia old Polish meads such as: 'Półtorak', 'Dwójniak', 'Trójniak', 'Czwórniak' and traditional sausages - 'Kiełbasa jałowcowa', 'Kiełbasa myśliwska'. There are no fresh or processed fruits or vegetables registered under the TSG scheme.
Since they have been registered they can be used by any producer who follows the same specification. Their 'specific' character refers to the feature or set of features which distinguish them clearly from other similar products or foodstuffs belonging to the same category. Even if they often come from a particular country or region, but their international reputation may result in making producers in other countries interested in producing according to the same specification.

\section{THE ECONOMICS OF GEOGRAPHICAL INDICATIONS}

The economics of geographical indications (GIs) is different from that of other forms of intellectual property (IP) protection. The main trade-off in IP protection is between the granting of a temporary monopoly to patent holders to encourage innovation and the restrictions that this imposes on imitators who could use that invention or innovation to produce goods for sale at lower costs. In the case of GIs, no invention is protected (Josling 2006). The protection is of a reputation associated with a quality attribute linked to a geographical area. In fact, innovation may itself be reduced by such protection (Giovannucci et al. 2009). However, place of origin is used as an quality attribute and resources of the region (such as production techniques, varieties and species, but also landscape, environment and culture) are used to increase the value of the product. The added value derived from these resources leads to a differentiation based on product 'qualities' and consequently to the creation of niche markets. The collective monopolies which result from the institutionalization process provide producers within origin-labelled niche markets the opportunity to protect and enhance their market and to transform the value added into an economic rent.

It could be said that geographical indications are the result of a process whereby collective reputation is institutionalized in order to solve certain problems that arise from information asymmetry and free riding on reputation (Bramley 2011). As such, the GI protection functions as both a consumer protection measure (through addressing information asymmetries and quality) and a producer protection measure (through its role in protecting reputation as an asset). The economic benefits of GIs must rest in large part on the provision of adequate information to consumers who may need help in making wise choices in their buying decision process as well as 


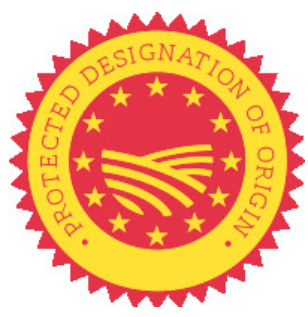

a)

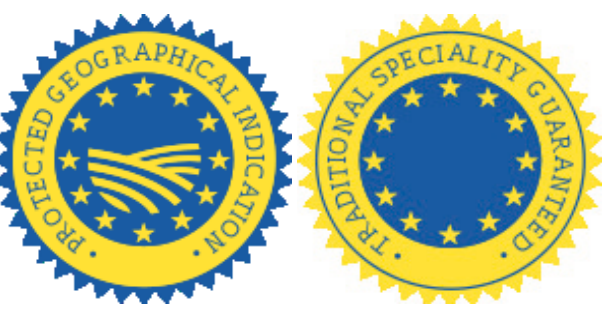

c)

Figure 1. PDO, PGI, TSG logos

on effective verification and controls of producers of GI products to eliminate unfair competition.

\section{BENEFITS AND COSTS RELATED TO GEOGRAPHICAL INDICATIONS AND TRADITIONAL SPECIALITIES DESIGNATIONS}

As globalisation spreads, foreign competitors are putting greater pressure on EU farmers. Geographical indications and traditional specialities are a potentially unique form of competitive advantage, even for small business. They are not easy to erode because they depend less on common factors of competition such as cost of production. Instead, they enable to develop differentiation strategy (as alternative to the low cost) based on unique local factors born of tradition, know-how, and special agro-ecological endowments.

However, many experts caution that it is not an easy achievement and that pursuing a differentiated strategy based on special quality names will not be the optimal answer in a number of cases (Josling 2006). First of all, the costs of developing such name extends far beyond the direct costs of actually filling for registrations, it also creates costs related to applying to rules, methods, and specifications; costs of control; marketing costs etc. There are also some distinct external factors, that determine success of such strategy more than any others. They comprise among others the existence of strong organizational and institutional structure, including producers associations; equitable partnership; strengths of market partners - mainly firms that can distribute the product and undertake its promotion; effective legal protection. In case of the absence of such pre-conditions, it may be better targeted towards development other strategies. However, if thoroughly managed, special quality product names can deliver many benefits, both to producers and consumers as well as to the whole regions.
The literature analysis (Barjolle and Sylvander 2000, Marescotti 2003, Belletti et al. 2007, London Economics 2008, Giovannucci et al. 2009, Belletti and Marescotti 2011) allows to identify some key benefits attributable to the use of PDO/PGI/TSG logo essential for the producers:

- receiving protection against unfair competition - only producers complying with the specification may use the name,

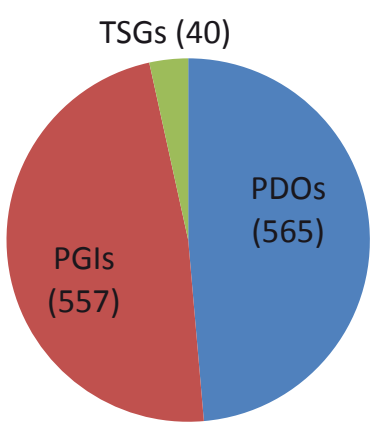

Figure 2. Number of registrations under PDO, TSG, PGI Schemes (excluding wines and spirits); June 2013 Source: DOOR database

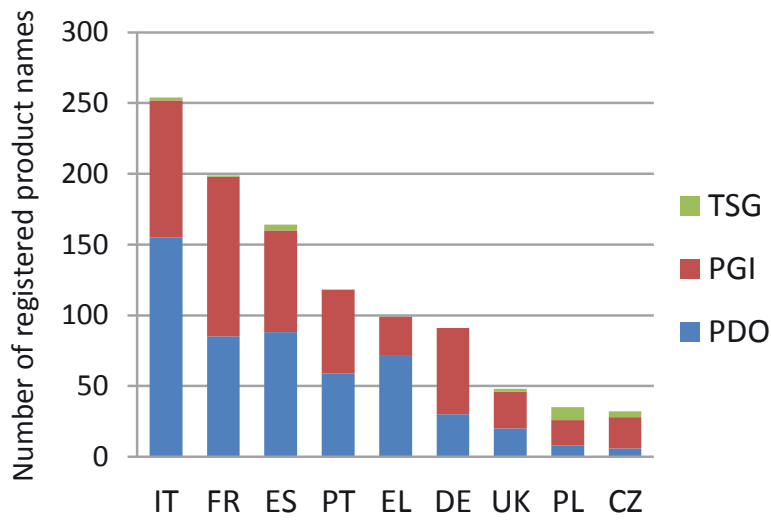

Figure 3. EU countries with the highest number of registered PDO, PGI and TSG product names; June 2013 Source: DOOR database 
- commanding a considerable price premium over similar products of the same category,

- increasing sales through the same international distribution channel,

- facilitating the opening of new distribution channels,

- steadying commercial relations and reducing uncertainty on the trade and final markets as regards to volumes and/or prices of exchanged PDO and PGI products,

- benefiting from collective product promotion thanks to the presence of a collective organisation in charge of organising, defending and promoting represented PDO or PGI production system,

- having the opportunity to use EU promotion funds for quality products,

- offering more guarantees to final consumers (traceability of the product and its production process),

- increased differentiation of protected products on foreign markets,

- benefiting from good reputation of geographical names of origin of protected PDO and PGI products.

Consumers also benefit, having a guarantee, via the quality systems and logos, that they are buying authentic high quality foodstuffs and that cheap ingredients were avoided in the manufacturing process. The main benefits for consumers have been identified as follows:

- providing reliable information about the origin of products and their characteristics and traditional methods of production,

- guaranteeing that the products are genuine articles, not fakes or imitations,

- making sure that the food has been produced in accordance with the detailed specification,

- giving the ability to recognize and acquire by consumers products from their region or other regions.

The development production, domestic sales and exports of quality products can also contribute to agricultural and rural economy. If more addedvalue production remains in rural areas, whole communities can benefit from: the maintenance of economic activities; improved job opportunities; spin-offs for other rural activities such as tourism (sometimes this additional activity will be on-farm), complementary effect on other products in region, elevated land values, socio-cultural valorisation etc. However it is discussed in literature, to what extend and under what conditions regional and traditional products can stimulate rural development, especially in marginal rural areas (Marescotti 2003). Some recent studies point out that in some regions $\mathrm{PGI} / \mathrm{PDO} / \mathrm{TSG}$ products are located mainly in more developed areas. As a consequence, the presence of such products could be the result rather than the cause of the development of rural areas.

The importance attributed by the European Union to the development of the activity in the field of product quality is reflected in the proposals of the support provided by EU to the producers of regional and traditional products. The Rural Development Programme RDP for 2007-2013, approved by the European Commission in July 2007, is providing within Axis 1 special support for producers and producer groups involved in EU and national food quality schemes.

\section{REGISTERED PDO, PGI AND TSG NAMES TO DATE}

Agricultural producers in European Union become more and more interested in using geographical indications to differentiate their products on the international markets and thus improve their competitiveness and profitability. The source of statistics on the use of product quality schemes, presented in this article is the DOOR database of the European Commission, which includes product names for foodstuffs registered as PDO, PGI or TSG as well as names for which registration has been applied (the analysis covers only already registered names). By June 2013 the total number of product names registered within three European Quality Schemes was 1162, with similar shares of PDOs and PGIs which together accounted for more than $96 \%$ of total number of registrations. TSGs represented only $3.4 \%$ of all product registrations (Fig. 2). To compare with, on January $1^{\text {st }} 2005$ 657 product names were registered under all three schemes. However, continuously low numbers of TSGs rises questions about possible weaknesses of the scheme.

The leading member state with the highest number of registrations was Italy (254 registrations), the second state was France (199 registrations) and the third was Spain (164 registrations). The countries with the highest number of product names registered under PDO/PGI/TSG schemes, especially Italy and France, have a long history of protecting and promoting products at national level. It is also worth mentioning that the EU's quality designation systems have for a long time been open 


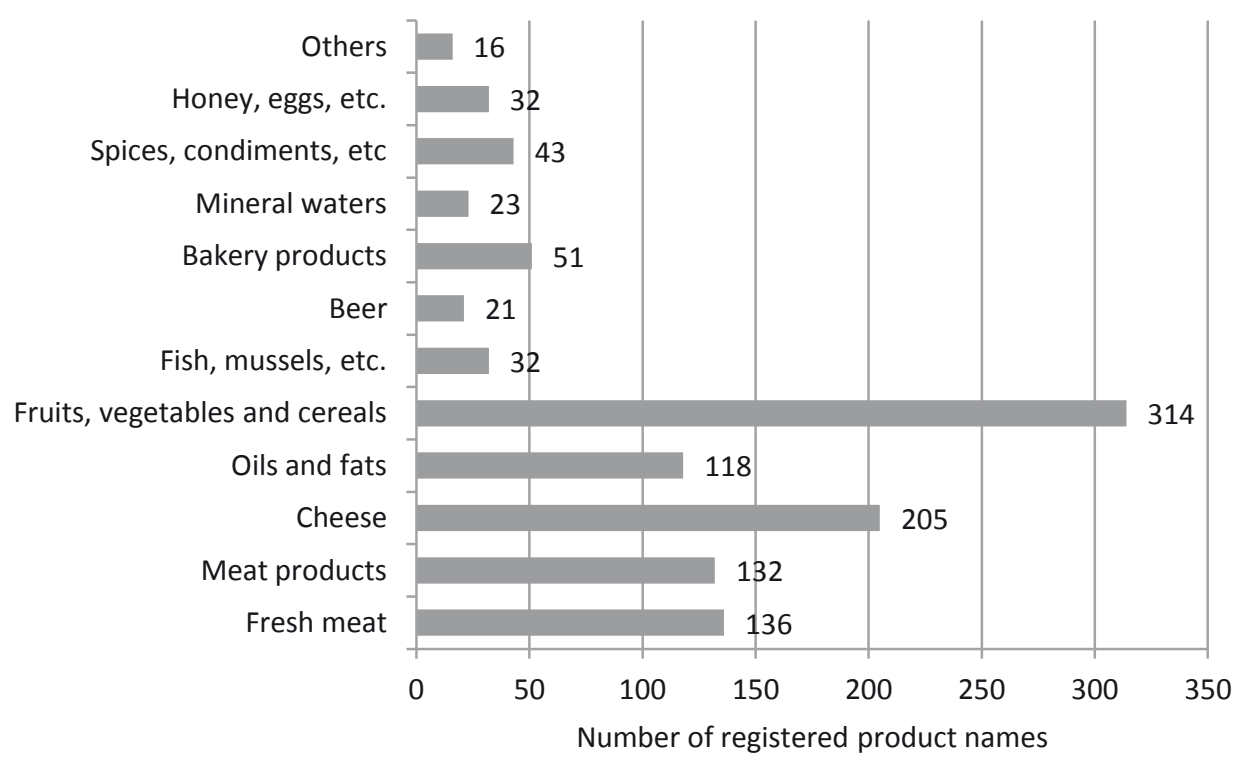

Figure 4. Registered PDOs, PGIs and TSGs by product group; June 2013

Source: DOOR database

to producers in non-EU countries, in conformity with multilateral trade rules of the World Trade Organization. Since 31 March 2006, applications for registration of PDOs, PGIs and TSGs by producers in third countries, and objections to applications by individuals in third countries, can be made even easier, directly to the Commission. However the number of international registrations is very low.

In 2012 Poland was at the $8^{\text {th }}$ rank among the 27 EU member states with 35 product names registered under the quality schemes: 8 as PDO, 18 as PGI or 9 TSG (Fig. 3). The latter number shows that Poland is the most active user of TSG scheme.
The main sectors in terms of $\mathrm{PDO} / \mathrm{PGI} / \mathrm{TSG}$ registrations were fruits and vegetables (with 314 names registered), cheese, fresh meat, meat products and oils and fats (Fig. 4).

Among 314 names of fruit and vegetables registered under the quality schemes more than $30 \%$ were Italian, numerous registered names originated also from Spain, France and Greece. Poland held the $7^{\text {th }}$ position with the 9 names registered (Fig. 5).

Polish names of fruits and vegetables registered under PDO/PGI schemes are to date: Truskawka kaszubska (strawberry variety from the Kashubia region), Wiśnia nadwiślanka (Vistula cherry),

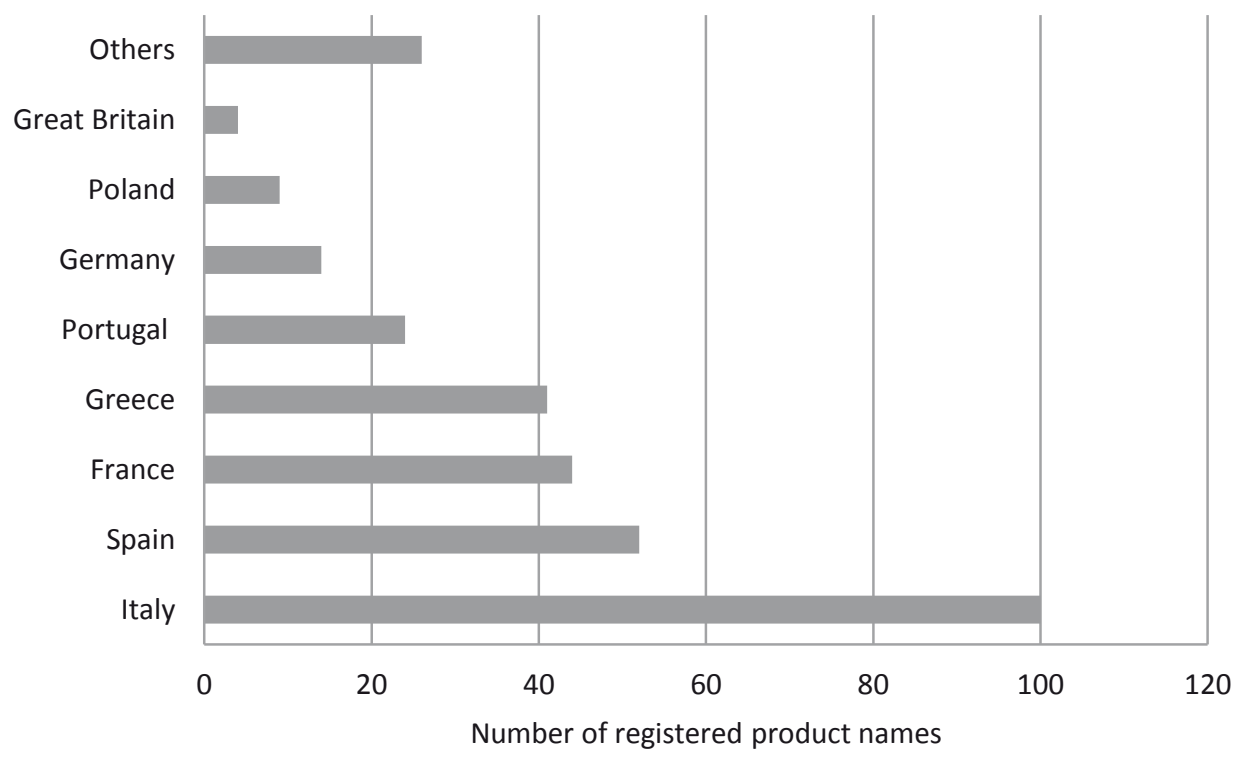

Figure 5. Registered names of fruits, vegetables and cereals under PDO/PGI by country; June 2013 Source: DOOR database 
Fasola korczyńska (bean variety from the Nowy Korczyn area), Śliwka szydłowska (dried plum from Szydłów), jabłka łąckie (apple variety from the Małopolska region), Jabłka grójeckie (apple variety from Grójec, Mazovia region), Fasola Piękny Jaś z Doliny Dunajca/Fasola z Doliny Dunajca, Fasola Wrzawska (bean variety from the Podkarpacki region), Suska sechlońska (dried plum from the Małopolska region).

\section{PRICES AND SALES OF PDO/PGI PRODUCTS}

The AND-International study performed in 2012 for the European Commission on the value premium of products bearing a GI names (PDOs and PGIs) estimated that in average GI products were sold 2.23 times as high as a comparable nonGI products. For wines the premium rate was at 2.75 , for spirits at 2.57 and for agricultural products and foodstuffs (excluding wines and spirits) the premium rate was 1.55 . This does, however, not mean that GI producers' margins are as much higher, since GI producers often face additional costs due to compliance with the GI specification.

The value premium reflects the premium that a GI can expect from the market, compared to similar non-GI products. Obviously the value premium rate was higher for the processed and elaborated products (such as meat processed products and olive oil) than for the raw and fresh ones (fruits and vegetables, fish or fresh meat). It varied from 1.8 in case of meat products to 1.16 for fish and fresh
Table 1. Value premium rate for agricultural products and foodstuffs under PDO/PGI schemes in 2010 (Source: AND - International 2012)

\begin{tabular}{lc}
\hline Product category & Value premium rate \\
\hline Meat products & 1.80 \\
Olive oil & 1.79 \\
Beers & 1.62 \\
Cheeses & 1.59 \\
Fruits and vegetables & $\mathbf{1 . 2 9}$ \\
Fish, molluscs and crustaceans & 1.16 \\
Fresh meat & 1.16 \\
\hline
\end{tabular}

meat. For fruits and vegetables it was at 1.29 (Tab. 1). The higher value premium rate was explained by the fact that the processing specification creates further differences in the product (presentation, taste, etc.) and extra costs too.

A successful PDO, PGI or TSG with good market recognition can not only create value, but also increase demand for the quality products and boost sales.

The above mentioned AND-International research estimates the worldwide sales value of agricultural products and foodstuffs registered under GI scheme in the EU 27 at 15.8 billion EUR in 2010 at wholesale stage in the region of production; it increased by $19 \%$ between 2005 and 2010. The main sectors in terms of sales value were cheeses $(40 \%$ of the total EU sales), meat products $(20 \%)$ and beers $(15 \%)$. Fresh meat and fruit and vegetables represented respectively $8 \%$ and $6 \%$ of the total sales (Tab. 2). The domestic

Table 2. Sales value of PDO/PGI agricultural products and foodstuffs at wholesale level by product group in the EU 27 between 2005 and 2010 in million EUR (Source: AND - International 2012)

\begin{tabular}{lrrrrrrr}
\hline Product category & \multicolumn{1}{c}{2005} & \multicolumn{1}{c}{2006} & 2007 & 2008 & 2009 & 2010 & $\%(2010)$ \\
\hline Cheeses & 5276 & 5289 & 5489 & 5651 & 5778 & 6307 & $40 \%$ \\
Meat products & 2395 & 2451 & 2579 & 2759 & 3095 & 3157 & $20 \%$ \\
Beers & 2301 & 2407 & 2361 & 2366 & 2390 & 2364 & $15 \%$ \\
Fresh meat & 1037 & 1011 & 1095 & 1116 & 1155 & 1244 & $8 \%$ \\
Fruits, vegetables and cereals & $\mathbf{7 7 1}$ & $\mathbf{7 6 4}$ & $\mathbf{9 0 1}$ & $\mathbf{8 6 4}$ & $\mathbf{8 4 9}$ & $\mathbf{9 7 8}$ & $\mathbf{6 \%}$ \\
Fresh fish, molluscs, and crustaceans & $\mathrm{S}$ & $\mathrm{S}$ & $\mathrm{s}$ & $\mathrm{s}$ & $\mathrm{S}$ & 443 & $3 \%$ \\
Other products of Annex I* & 107 & 102 & 124 & 144 & 134 & 369 & $2 \%$ \\
Oils and fats & 359 & 377 & 335 & 348 & 343 & 346 & $2 \%$ \\
Bread, pastry, cakes...... & 291 & 268 & 280 & 284 & 272 & 279 & $2 \%$ \\
Natural mineral and spring waters & 145 & 146 & 144 & 145 & 143 & 143 & $1 \%$ \\
Other products of animals origin & 48 & 45 & 47 & 49 & 68 & 71 & $0 \%$ \\
Others & 25 & 68 & 71 & 73 & 55 & 87 & $1 \%$ \\
Total & 13284 & 13457 & 13891 & 14238 & 14525 & 15790 & $100 \%$ \\
\hline
\end{tabular}

$\mathrm{s}-$ statistical confidentiality

*other non processed agricultural products listed in the Annex I of the Treaty on the functioning of the EU 
Table 3. Breakdown of sales volume and sales value (\%) per category in fruit, vegetables and cereals sector in 2010 (Source: AND - International 2012)

\begin{tabular}{lcc}
\hline Product & Sales volume & Sales value \\
\hline Fruits & 84 & 65 \\
Vegetables & 13 & 32 \\
Cereals & 4 & 3 \\
Total & 100 & 100 \\
\hline
\end{tabular}

market constitutes the most important one for GI agricultural products and foodstuffs. It accounted for $78 \%$ of the total sales value, while intra-EU trade reached $16 \%$ and extra-EU trade $6 \%$ (export share increased from 4\% between 2005 and 2010).

Assessing the importance of GIs in EU fruits, vegetables and cereals sector, the research estimates the sales value of fruit, vegetables and cereals under the PDO/PGI schemes in the EU 27 in 2010 at 978 million EUR, the sales volume at $922500 \mathrm{t}$. Fruit was the main category with $84 \%$ of the sales volume and $65 \%$ of the sales value (Tab. 3 ).

With $34 \%$ of the sales value, Italy was the main actor of this sector. The second was France (20\%). The next countries were the United Kingdom and Spain. Italy represented about half the sales value of the fruit sector, the United Kingdom accounted for more or less the same share of the vegetable sector and Spain represented $80 \%$ of the sales value of the cereal sector (rice production).

However, GI products represented only $1.5 \%$ of the national fruit sector in Italy in 2009 and $0.9 \%$ of the national fruit sector in France in 2008.

\section{CASE STUDY - 'WIŚNIA NADWIŚLANKA', PDO}

In December 2009, 'Wiśnia nadwiślanka' (The Vistula Cherry) has been registered as the protected designation of origin by the European Commission. It was the fifteenth Polish product receiving UE protection and the first Polish PDO, other than cheese, and not originating from Podhale.

\section{Main characteristics of the 'Wiśnia nadwiślanka' fruit}

The name 'Wiśnia nadwiślanka' refers to the local type of suckering 'sokówka' sour cherry tree that has become common along the river Vistula (Polish: Wisła), hence the name meaning 'cherry from along the Vistula'. It is adapted to the local climate and soil conditions, in particular to a calcareous or calcareous-clay soil occurring in this region of Świętokrzyskie voivodeship and the proximity of the river.

This cherry tree has been selectively derived from the European dwarf cherry, which propagates vegetatively by means of root suckers. Closely related to the steppe cherry (Prunus fruticosa Pall.), it belongs to the family Rosaceae Juss., subfamily Prunoideae, genus Prunus L., subgenus Cerasus (Mill.). This relatively primitive, from the viewpoint of plant breeding, local cherry variety is characterized by high expansiveness, which relates to the fact that five years after planting, cherry trees of this type grow root suckers for propagation.

The term 'sokówka', signifies that the fruit is mainly used for making juice (Polish: sok). In fact, fruits of 'Wiśnia nadwiślanka' has long been appreciated as a dessert fruit and a product for use in the processing industry, thanks to their unique flavour, colour and aroma.

The characteristic features of 'Wiśnia nadwiślanka' are as follows (European Commission, notice No 2009/C 104/09):

- fruit size considerably smaller than in cultivars (the diameter of the fruit seldom exceeds $20 \mathrm{~mm}$, usually ranges between 12 and $20 \mathrm{~mm}$ and its weight is $1.6-3.3 \mathrm{~g}$, varying significantly depending on the age and location of the tree),

- the flesh of the cherry having intense colour; the stone is dark and of a colour similar to that of the flesh, very intense colour, ranging from dark red to burgundy, uniform over the whole surface of the fruit, the fruit's intense colour is maintained even after processing,

- very high anthocyanin content: more than

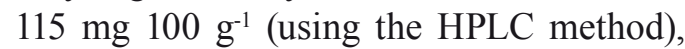
this is at least 20 percent higher than in the ' $Ł u$ úwka' cherry, which is considered to be the best for processing. The difference can reach up to 100 per cent, depending on the weather in a given year and the position of the trees. Anthocyanins are substances with anticarcinogenic properties. This unusually high anthocyanin content in the 'Vistula Cherry' could play a major role in cancer prevention.

- high refractometric index: $16-23^{\circ} \mathrm{Bx}$,

- high sugar content: more than $13 \%$,

- high acidity (organic acid content), at least $1.4 \%$ expressed as malic acid, at a $\mathrm{pH}$ of 8.1.

The fruit is round and slightly oblate. The stoneto-fruit weight ratio depends on the age of the trees, 
ranging from $9.4 \%$ to $11.3 \%$. The fruit is aromatic, and its taste and smell are characteristic of cherries, the taste being very intense and slightly tart. The fruit is excellent for making cherry concentrate and preserves; due to a high extract level and acidity. The concentrate gains a much better colour and aroma from a smaller amount of fruit.

Comparison of 'Wiśnia nadwiślanka' with other sour cherry cultivars shows that its total extract is higher than in case of other analysed cherries. The level of total extract indicates maturity of fruits, thus 'Wiśnia nadwiślanka' dominates over other cherry cultivars in regards to this characteristic. Even if its fruits are small, the share of stone in total weight is below the average for all analysed varieties (Tab. 4).

In accordance with the PDO scheme's requirements all steps in production must in this case take place in the identified geographical area. The region in which 'Wiśnia nadwiślanka' cherries are produced is situated along the river Vistula that includes the districts of Ożarów, Tarłów, Annopol, Lipsko, Sienno and Solec nad Wisłą and is characterised by unique environmental conditions and a calcareous or calcareous-clay soil. The combination of the effect of the locally occurring soils and the proximity of the river not only influences growth and flowering but also results in a high degree of fruit formation, after a short flowering period, thus allowing to obtain fruits of special qualities. Under these conditions, other species and cultivars grow poorly, and their fruiting is not satisfactory. Therefore, in plantings of fruit trees in the region, 'Wiśnia nadwiślanka' has a dominant position, bringing benefits to local population. In the area where these cherries grow, frosts are also liable to occur during the blossoming period, making for variability as regards fruit formation over the years, but their effect is minimised by the warming effect of the Vistula.

A significant development of 'Wiśnia nadwiślanka' cultivation occurred in the late twentieth century, due to the growing interest of foreign customers, when it began to compete with a well-known for its excellent processing parameters 'sokówka' cultivar - 'Stivens'. Attempts to adapt Stivens cultivar to the Polish conditions did not give successful results, thus 'Wiśnia nadwiślanka' remained the only fruit on the market with similar parameters of colour and aroma.

An important aspect of the area's specificity is the knowledge and skill of local producers, who have learned how to cultivate a cherry and to adapt cultivation methods to the prevailing soil and climatic conditions. This is reflected above all in the right choice of planting density and the method of removing suckers according to the type of soil in which this cherry tree is planted, and in the removal of root suckers starting from the fifth year of cultivation. The trees have relatively high disease resistance, but it is essential to select appropriate plant protection measures.

\section{Registration of the 'Wiśnia nadwiślanka' name}

Application for registration 'Wiśnia nadwiślanka' as PDO was submitted to the European Commission by Spółdzielnia Producentów Owoców i Warzyw NADWIŚLANKA (The Nadwiślanka Fruit and Vegetable Producers' Cooperative) in Ożarów.

The cooperative was established in February 2005 following the year of natural oversupply of soft fruits. In 2006 the Group succeeded in placing The 'Vistula Cherry' on the Polish Ministry of Agriculture and Rural Development's list of traditional products. In December 2006 the Cooperative initiated the registration process for the EU product quality designation. As a result, in 2009 'Wiśnia nadwiślanka' was granted a status of 'Protected Designation of Origin'. Due to the fact that Spółdzielnia NADWIŚLANKA was requesting $\mathrm{PDO}$ registration, it leads the register of members who grow 'Wiśnia nadwiślanka' and who annually certify their production. Supervision

Table 4. Parameters of 'Wiśnia nadwiślanka' as compared to other sour cherry cultivars in the years 2009-2011 (Suszyna 2012)

\begin{tabular}{lccc}
\hline Cultivar & Total extract $\left({ }^{\circ}\right.$ Brix $)$ & Weight of 100 stones $(\mathrm{g})$ & Share of stone in total weight $(\%)$ \\
\hline Kelleris 16 & 14.2 & 43.9 & 8.8 \\
Groniasta & 15.0 & 58.1 & 10.3 \\
Lutówka & 14.9 & 54.5 & 12.0 \\
Pandy 113 & 14.6 & 61.5 & 9.0 \\
Nadwiślanka & $\mathbf{1 8 . 7}$ & $\mathbf{3 8 . 5}$ & $\mathbf{9 . 4}$ \\
Average & 15.4 & 51.3 & 9.9 \\
\hline
\end{tabular}


Table 5. Cultivation area and production of certain tree fruits in Poland (according to The Institute of Agricultural and Food Economics, National Research Institute, Poland)

\begin{tabular}{lrrrrrrrr}
\hline \multirow{2}{*}{ Product category } & \multicolumn{3}{c}{ Cultivation area } & (thousand ha) & \multicolumn{3}{c}{ Production of fruits (thousand tonnes) } \\
& 2009 & \multicolumn{1}{c}{2010} & \multicolumn{1}{c}{2011} & 2012 & \multicolumn{1}{c}{2009} & \multicolumn{1}{c}{2010} & \multicolumn{1}{c}{2011} & \multicolumn{1}{c}{2012} \\
\hline Total: tree fruits and nuts & $\mathbf{2 8 1 . 9}$ & $\mathbf{2 7 9 . 5}$ & $\mathbf{2 9 6 . 3}$ & $\mathbf{2 9 5 . 4}$ & $\mathbf{3 1 0 2 . 9}$ & $\mathbf{2 2 2 0 . 0}$ & $\mathbf{2 8 8 7 . 0}$ & $\mathbf{3 2 9 0 . 0}$ \\
Apples & 173.6 & 170.4 & 183.5 & 194.7 & 2626.3 & 1877.9 & 2493.1 & 2877.3 \\
Pears & 13.2 & 8.4 & 11.7 & 10.8 & 83.0 & 46.5 & 62.8 & 64.7 \\
Plums & 21.0 & 17.9 & 20.2 & 19.3 & 120.7 & 83.8 & 91.8 & 102.5 \\
Sour cherries & $\mathbf{3 5 . 5}$ & $\mathbf{3 3 . 0}$ & $\mathbf{3 4 . 0}$ & $\mathbf{3 3 . 7}$ & $\mathbf{1 8 9 . 2}$ & $\mathbf{1 4 7 . 2}$ & $\mathbf{1 7 5 . 0}$ & $\mathbf{1 7 5 . 4}$ \\
Cherries & 10.6 & 12.0 & 11.6 & 11.6 & 50.5 & 40.1 & 38.0 & 41.1 \\
\hline
\end{tabular}

of the quality system is performed by certification bodies: PNG and BioCert.

\section{Cultivation area and production of 'Wiśnia nadwiślanka'}

In 2012, the planted acreage of 'Wiśnia nadwiślanka' was about 1000 ha, which accounts for $3.4 \%$ of total area of sour cherry cultivation in Poland (Tab. 5). There are about 500 producers of 'Wiśnia nadwiślanka' in total, but only 33 of them have been certified under PDO scheme. They are the 'avantgarde' in creating a food quality system, and their production is the showcase of the region. In terms of the Świętokrzyskie voivodeship (the average farm size of 6 ha), certified 'Wiśnia nadwiślanka' farms can be considered as medium sized. Because the commodity production of these farms is dominated by the cultivation of cherries, they should be also considered as specialized. They have specialised equipment and machinery used only for this crop, such as convector sprayers, herbicide beams, sucker movers, etc. The professionalism of farmers can also be proved by possessing formal agricultural education and years of practice in growing cherries. Cultivation of local variety of suckering 'Sokówka' cherry is also conducted by a number of small farms, but they do not take up the certification procedure.

As it is shown in Table 6, in 2012 the total volume of certified production of 'Wiśnia nadwiślanka', reached $317268 \mathrm{~kg}$. That level of production was lower compared to the years 2010-2011, which was mainly due to the low yield of these cherries, as a result of the poor weather conditions that year, affecting pollination and fertilization of flowering plants. Low yields were partially offset by higher prices of fruits.

\section{Strategic buyer and prices of 'Wiśnia nadwiślanka'}

The cooperative closely cooperates with Materne Poland Co. Ltd. in Łopatki, one of the biggest and most important companies purchasing, processing and exporting fruits from Polish producers. Materne Poland Co. Ltd., operating in Poland since 1992 is a part of the French Andros Company-the European leader of fruit market. Andros possesses a dozen of plants which contributes to the leading position in the following fields: fruit preserves (jam, confiture, juices, mousses), confectionery, bakery and fresh dairy products. Having Materne as a buyer, which account for $60-70 \%$ of total 'Wiśnia nadwiślanka' sales, results in slightly higher prices - about $5 \%$ higher than for other cherry cultivars (in the same quality category) in the years of fruit abundance and even up to $20 \%$ higher in the years of scarcity of fruit. Materne appreciates quality of the cherry and ensures higher price stability and reduced fluctuations of sales for 'Wiśnia nadwiślanka', at the same time the company imposes stricter quality control of fruit at every stage of their growth.

Materne Poland is a strategic buyer, however not the only one. Each recipient if they can choose between the 'Vistula Cherry' and 'Łutówka' priced at the same level they always choose the first one. Due to valuable parameters of 'Wiśnia nadwiślanka'

Table 6. Certified production of 'Wiśnia nadwiślanka' (Dziewirz 2013)

\begin{tabular}{|c|c|c|c|c|}
\hline \multirow{2}{*}{ Year } & \multirow{2}{*}{ Number of participants } & \multirow{2}{*}{ Certified production (kg) } & \multicolumn{2}{|c|}{ Value of certified production } \\
\hline & & & zł & euro \\
\hline 2010 & 28 & 480388 & 920254 & 230375 \\
\hline 2011 & 31 & 787853 & 1554424 & 377306 \\
\hline 2012 & 33 & 317268 & 1192100 & 284851 \\
\hline
\end{tabular}


and a lack of rigidly divided suppliers' market, farmers don't risk that fruit remain unsold. Strongly promoted pro health attributes of anthocyanin can actually create another strategic recipient for the Vistula cherry.

In 2012 average prices paid to producers of 'Wiśnia nadwiślanka' were at the level of $3.75 \mathrm{zl}$ per $\mathrm{kg}$ ( 0.9 euro), as compared to $2 \mathrm{zl}$ per $\mathrm{kg}(0.5$ euro) in 2011 and 1.91 zf (0.48 euro) in 2010. Since 'Wiśnia nadwiślanka' has been registered as PDO it recorded a 10 percent increase in sales over other types of cherries, what was already a significant achievement. However, the price and sales growth, which has been noted in recent years, do not fully compensate for the high cost of production of 'Wiśnia nadwiślanka'. The cost of production of the cherry is influenced by the factor, inter alia, that the 'Vistula Cherry' is mainly picked manually. The cost of hired labour is 30 gr per kilogram (about 7 cents) in case of other cherries (picked by machines), as compared to $50 \mathrm{gr}$ (about 11 cents) in case of 'Wiśnia nadwiślanka'. Second, the average yield of 'Wiśnia nadwiślanka' is lower. While in the region of Sandomierz yield of grafted cultivar is at 20 tonnes per hectare, the 'Vistula Cherry' yield is at 10 tons. According to the experts, the cherry's price should be $30 \%$ higher over other cherry cultivar in order to make its production profitable and to attract new farmers to join the scheme. Especially that functioning in the system is cumbersome, due to the obligation to keep certain records and to make timely notifications and payments. Producers also have to undergo the certification procedure and then frequent controls of the compliance with the specification reported to the EU. Thus, the price level is currently one of the main concern for producers of 'Wiśnia nadwiślanka'.

Price premium of $30 \%$ seems to be difficult to obtain, at least in case of fruits sold for food processing, due to very strong pressure exerted by big retailers (especially discount stores) on fruit processors to lower prices of their products. However, certified producers of 'Wiśnia nadwiślanka' should be able to strengthen market positioning of their product as "good for health" and sell more of quality fruit for freezing, for which they can charge higher prices on the market.

As it is shown in Table 7, prices paid to producers of 'Wiśnia nadwiślanka' for quality high fruits (which refer mainly to the purchases of certified cherry) are significantly higher than for fruits for processing. The price difference between relatively low prices for sour cherries for extrusion and higher price level for cherries for freezing ranges from $0.163 \mathrm{zł}$ per kg in 2012 to $0.408 \mathrm{zł}$ per kg in 2010.

\section{Benefits and challenges under PDO scheme for 'Wiśnia nadwiślanka' producers}

Participation in PDO scheme helps producers to communicate the outstanding characteristics of the cherry as a quality fruit with its anticarcinogenic properties to consumers and distributors, both in Poland and abroad. 'Wiśnia nadwiślanka' is already appreciated by buyers on French and German markets, mainly for its high sugar content. Declining production of these fruits in Western Europe can create new export opportunities.

So far the main positive effects of registering "Wiśnia nadwiślanka" under the PDO scheme are:

1) promoting the cherry at the regional, national and European level,

2) observing the first signs of asking for the cherry by processors and consumers (the so called "pull" effect in marketing),

3) receiving higher prices from buyers who appreciate quality (even if premium over other types of cherries is still not sufficient).

Cherry producers can also receive a financial support as the beneficiaries of The Rural Development Programme for 2007-2013 under the measure 132 of RDP "Participation of farmers in food quality schemes". Within the framework of

Table 7. Prices paid to producers of sour cherry by The Nadwiślanka Fruit and Vegetable Producers' Cooperative's in years 2009-2013 (according to the Cooperative's notifications)

\begin{tabular}{lcccccc}
\hline Year & $\begin{array}{c}\text { Fruit for freezing or dessert fruit } \\
\text { price per kg } \\
\text { (PLN) }\end{array}$ & $\begin{array}{c}\text { price per kg } \\
\text { (EUR) }\end{array}$ & $\begin{array}{c}\text { Fruit for extrusion } \\
\text { price per kg } \\
\text { (PLN) }\end{array}$ & $\begin{array}{c}\text { price per kg } \\
\text { (EUR) }\end{array}$ & $\begin{array}{c}\text { Price difference } \\
\text { price per kg } \\
\text { (PLN) }\end{array}$ & $\begin{array}{c}\text { price per kg } \\
\text { (EUR) }\end{array}$ \\
\hline 2009 & 0.723 & 0.167 & 0.498 & 0.115 & 0.225 & 0.052 \\
2010 & 2.127 & 0.532 & 1.719 & 0.430 & 0.408 & 0.102 \\
2011 & 2.285 & 0.555 & 1.943 & 0.472 & 0.342 & 0.083 \\
2012 & 3.174 & 0.758 & 3.011 & 0.719 & 0.163 & 0.039 \\
2013 & 1.927 & 0.459 & 1.66 & 0.395 & 0.267 & 0.064 \\
\hline
\end{tabular}


this Programme they obtain reimbursement for participation in the system in the amount of $3200 \mathrm{zl}$ (about 750 euro) per year per household. According to the EU intention this financial support is to compensate for additional costs and obligations arising from participation in the scheme. It covers only the cost of certification and the contribution to the group of producers. It doesn't provide extra profit. Extra gains should be ensured by obtaining a premium price what would be the expected result for the producers.

The Nadwiślanka Fruit and Vegetable Producers' Cooperative offers support to farmers operating in the system, providing them in training, intermediating in the sales of fruit, organizing a block-certification, helping them to complete all the required documents and to buy certain pro-quality plant protection measures with a discount. But first of all, the cooperative makes efforts to ensure that the producers of this outstanding cherry obtained the highest possible price for it, so they don't need to limit its cultivation. This goal can be pursued mainly by promoting cherry parameters and trying to convince buyers they should pay a premium price for high quality fruit. The growing awareness of consumers as to healthy food and their interest in quality products creates a market opportunity for producers of the' Vistula Cherry'. The main economic threat refers to impoverishment of the society in the crisis and their bigger price sensitivity (Suszyna 2013).

In order to strengthen the market position of 'Wiśnia nadwiślanka' producers their activity should be more focused on creating value added by undertaking further stages of fruit processing, stronger horizontal integration, and the unification of technology for disease control and fertilization. Improved integration should allow producers to make better use of the market mechanisms to improve the stability and profitability of the crop of cherries, despite lower yields compared to grafted cultivars. Moreover, in order to be able to sell more products as dessert fruits, producers must improve the logistics and develop refrigerated storage facilities. Foreign customers want to buy a dessert cherry in individual packages weighing from 100 to 300 grams. The packing should take place directly in the orchard, then fruit must be chilled immediately in refrigerated storage. The cooperative has significantly improved its logistics facilities in recent years, but individual farmers are not yet fully prepared for such operations. Improving logistics and intensive promotional activities seem to be necessary, in order to obtain better price for high quality product and to make growing the 'Vistula Cherry' more profitable to producers.

\section{CONCLUDING REMARKS}

The growing interest of consumers in quality and traditional products generates a demand for agricultural products or foodstuffs with identifiable specific characteristics, in particular those linked to their geographical origin and a method of production. Operating in the European Union three quality schemes for producers are aimed at helping agricultural producers of regional and traditional products to communicate the unique product characteristics to buyers and consumers thus supporting their efforts to win the competition based on quality.

Registering product under the PDO/PGI/ TSG logo usually allows a producer to command a considerable price premium over similar products of the same category, but at the same time generates cost related to applying to rules, methods, and specifications; costs of control; marketing costs etc.

In order to fully benefit from the system and thus improve stability and profitability of production, producers, in addition to meeting certain pre-conditions, must constantly develop their own production and marketing skills, within the framework of strong producers associations.

\section{REFERENCES}

AND - InTERNATIONAL, 2012. Value of production of agricultural products and foodstuffs, wines, aromatised wines and spirits protected by a geographical indication (GI). Final report by the European Commission and AND International, Oct. 2012.

BARHAM E., 2003. Translating terroir: the global challenge of French AOC labelling. J. Rural Stud. 19: 127-138.

Barjolle D., Sylvander B., 2000. Some factors of success for origin labelled products in agrifood supply chains in Europe: market, internal resources and institutions. In: B. Sylvander, D. Barjolle and F. Arfini (Eds). The Socio-Economics Of Origin Labelled Products In Agri-Food Supply Chains: Spatial, Institutional And Co-Ordination Aspects. INRA Actes et Communications 17-1: 45-71.

Belletti G., Burgassi T., Manco E., Marescotti A., Pacciani A., Scaramuzzi S., 2007. The roles of geographical indications (PDO and PGI) on the internationalisation process of agro-food products. 
Contributed Paper prepared for presentation at the 105th EAAE Seminar 'International Marketing and International Trade of Quality Food Products', Bologna, Italy, March 8-10, 2007. Available online at http://ageconsearch.umn.edu/bitstream/7851/1/ cp070035.pdf; cited on 09 July 2013.

Belletti G., Marescotti A., 2011. Evaluating the effects of protecting Geographical Indications: scientific context and case studies. In: Swiss Federal Institute of Intellectual Property (Ed.). The Effects of Protecting Geographical Indications. Ways and Means of their Evaluation, Berne, Publication n.7 (07.11): 31-121.

Bramley C., 2011. A review of the socio-economic impact of geographical indications: considerations for the developing World. Paper prepared for presentation at the WIPO Worldwide Symposium on Geographical Indications June 22 - 24 2011, Lima, Peru: 1-22. Available online at http://www.wipo.int/ edocs/mdocs/geoind/en/wipo_geo_lim_11/wipo_ geo_lim_11_9.pdf; cited on 15 July 2013.

Door database. Available online at: http://ec.europa.eu/ agriculture/quality/door/ list.html; cited on 15 July 2013.

Dziewirz F., 2013. „Wiśnia Nadwiślanka” w unijnym systemie jakości żywności. The Nadwiślanka Fruit and Vegetable Producers' Cooperative, IX Wojewódzkie Święto Kwitnącej Wiśni, Plantpress, Nowe.

European Commission, notice No 2009/C 104/09. Publication of an application pursuant to Article 6(2) of Council Regulation (EC) No 510/2006 on the protection of geographical indications and designations of origin for agricultural products and foodstuffs, 'Wiśnia Nadwiślanka'. Official Journal of the European Union, 2009.

European Commission, 2011. Europe, the taste of quality, Europe values the diversity of its quality products. European Commission, Directorate General for Agriculture and Rural Development, Luxembourg: Office for Official Publications of the European Communities, 2011.

European Commission, 2013. Agriculture and Rural Development, Geographical indications and traditional specialties. Available online at http:// ec.europa.eu/agriculture/quality/schemes; cited on 09 July 2013.

Giovannucci D., Josling T., Kerr W., O'Connor B., Yeung M.T., 2009. Guide to Geographical Indications: Linking products and their origins, International Trade Centre, Geneva.

Goodman D., 2003. The quality 'turn' and alternative food practices: reflections and agenda. J. Rural Stud. 19: 1-7.

Green PAPer on agricultural product quality: product standards, farming requirements and quality schemes, Commission of the European Communities, Brussels, 15.10.2008.
HegNes A.W., 2012. Introducing and practising PDO and PGI in Norway, Anthropology of Food. Available online at http://aof.revues.org/7210; cited on 09 July 2013.

Hughes D., 2002. Consumer interests and the reform of the CAP: a review of relevant documentation and research, Imperial College, University of London: 1-31. Available online at http://ec.europa.eu/ consumers/reports/rep02_en.pdf; cited on 09 July 2013.

Ilbery B., Kneafsy M., 2000. Producer constructions of quality in regional specialty food production: a case study from south West England. J. Rural Stud. 16: 217-230.

JosLing T., 2006. What's in a Name? The Economics, Law, and Politics of Geographical Indications for Foods and Beverages. Institute for International Integration Studies Discussion, Paper No. 109: Trinity College, Dublin: 1-33. Available online at http://www.tcd.ie/iiis/documents/discussion/pdfs/ iiisdp109.pdf; cited on 09 July 2013.

London Economics, 2008. Evaluation of the CAP policy on protected designations of origin (PDO) and protected geographical indications (PGI), London. Study financed by the European Commission.

Marescotti A., 2003. Typical products and rural development: Who benefits from PDO/PGI recognition? Paper presented at: Food Quality Products in the Advent of the 21st Century: Production, Demand and Public Policy. 83 ${ }^{\text {rd }}$ EAAE Seminar, Chania, Greece, 4-7 September. Available online at http://www.fao.org/fileadmin/templates/ olq/documents/documents/cherry $\% 20$ of $\% 20$ Lari\%20marescotti.pdf; cited on 09 July 2013.

Marsden T., Banks J., Bristow G., 2000. Food supply chain approaches: exploring their role in rural development. Sociologia Ruralis 40 424-438.

MARTy F., 1997. Which are the ways of innovation in PDO and PGI products? In: F. Arfini and C. Mora (Eds). Typical and Traditional Products: Rural Effect and Agro-Industrial Problems. Proceedings of $52^{\text {nd }}$ EAAE Seminar (19-21.6.1997), Parma. Available online at http://www.origin-food.org/pdf/eaae97/02 marty.pdf; cited on 09 July 2013.

Porter M., 1990. The Competitive Advantage of Nations, The Free Press, New York.

Regulation (EU) No 1151/2012 of The European Parliament and of The Council, of 21 Nov. 2012 on quality schemes for agricultural product and foodstuffs, Article 1.

SuszynA J., 2012. Wiśnia nadwiślanka w unijnym systemie jakości. The Nadwiślanka Fruit and Vegetable Producers' Cooperative, VIII Wojewódzkie Święto Kwitnącej Wiśni. Plantpress, Nowe.

Suszyna J., 2013. Szanse i zagrożenia uprawy 'Wiśni nadwiślanki'. The Nadwiślanka Fruit and Vegetable 
Producers' Cooperative, VIII Wojewódzkie Święto Kwitnącej Wiśni. Plantpress, Nowe.

WARNER K.D., 2007. The quality of sustainability: Agroecological partnerships and the geographic branding of California winegrapes. J. Rural Stud. 23: 142-155.

Received September 7, 2013; accepted February 3, 2014 